brazilianpoliticalsciencereview

ARTICLE

\title{
Corporate Dependence in Brazil's 2010 Elections for Federal Deputy*
}

\author{
Wagner Pralon Mancuso \\ Universidade de São Paulo, Brazil \\ Dalson Britto Figueiredo Fillho \\ Universidade Federal de Pernambuco, Brazil \\ Bruno Wilhelm Speck \\ Universidade de São Paulo, Brazil \\ Lucas Emanuel Oliveira Silva \\ Universidade Federal de Pernambuco, Brazil \\ Enivaldo Carvalho da Rocha \\ Universidade Federal de Pernambuco, Brazil
}

What is the profile of candidates whose electoral campaigns are the most dependent on corporate donations? Our main objective is to identify factors that help explaining the level of corporate dependence among them. We answer this question in relation to the 2010 elections for federal deputy in Brazil. We test five hypotheses: 01. right-wing party candidates are more dependent than their counterparts on the left; 02. government coalition candidates are more dependent than candidates from the opposition; 03. incumbents are more dependent on corporate donations than challengers; 04. businesspeople running as candidates receive more corporate donations than other candidates; and 05. male candidates are more dependent than female candidates. Methodologically, the research design combines both descriptive and multivariate statistics. We use OLS regression, cluster analysis and the Tobit model. The results show support for hypotheses 01,03 and 04 . There is no empirical support for hypothesis 05. Finally, hypothesis 02 was not only rejected, but we find evidence that candidates from the opposition receive more contributions from the corporate sector.

Keywords: Corporate dependence; elections; campaign finance; federal deputies.

(*) http://dx.doi.org/10.1590/1981-38212016000300004

For data replication, see bpsr.org.br/files/archives/Dataset_Mancuso et al

We thank the editors for their careful work and the anonymous reviewers for their insightful comments and suggestions. Co-author Dalson Britto Figueiredo Filho is thankful to the Berkeley Initiative for Transparency in the Social Sciences (BITSS) and to the Project Teaching Integrity in Empirical Research (TIER - Haverford College). He also appreciates the financial support provided by the Federal University of Pernambuco (UFPE). 
$\mathrm{T}$ he Brazilian legislative elections of 2010 allowed candidates to take advantage of a variety of sources of campaign finance. One of these sources was the state, which makes available free television and radio airtime, but also funds parties directly ${ }^{1}$. Other legal sources of campaign funding are self-funding of candidates, private donations from individuals and companies, the sale of goods, fundraising events and income from financial investments. This study is limited to corporate donations to candidates who ran for federal deputy in $2010^{2}$.

The financing of electoral campaigns by business is one of the principal forms of interaction between the corporate and political worlds (HAGGARD, SCHNEIDER and MAXFIELD, 1997). According to McMenamin (2009; 2012), a firm can contribute to electoral campaigns because of its ideological preferences, commitments arising from social ties to the recipient (e.g., friendship, family links, class identity, membership of the same social networks), a pragmatic desire to establish closer ties with the ruling party, or opposition parties with a greater chance of winning, independently of the profile of the recipient, and as reward for benefits given to the firm in the past - in the form of government contracts, favorable legislative or administrative decisions - and/or the expectation of gaining these benefits in the future.

The question of corporate political financing has been central to the debate on political reform in Brazil, for four reasons:

01. The amount of corporate money invested in elections is already high and increases with each election. According to data from the TSE, in the 2002 elections, direct corporate finance to Brazilian federal deputy candidates totaled BRL 110.2 million. In 2006, this number rose to BRL 211.8 million (an increase of $92.2 \%$ in a period of cumulative inflation of 35.5\%, according to IBGE's IPC-A, the official inflation index). In the 2010 elections, the amount rose to BRL 371.1 million (an increase of $75.2 \%$ with inflation of $28.7 \%)^{3}$.

1 TV and radio broadcasters received fiscal compensation, in accordance with laws 9.504/97, $12.034 / 09$ and 12.350/10. The free airtime is provided under laws 9.504/97, 11.300/06 and 12.034/09. The allocation of party funds was decided under laws 9.096/95 and 11.459/07.

${ }^{2}$ Company donations may also be directed to parties and electoral committees.

3 This paper is limited to donations made by companies and declared to the Electoral Court (Justiça Eleitoral) by the candidates, in accordance with laws 9.504/97, 11.300/06 and 12.034/09. Investigations conducted by bodies such as the Federal Police and the Federal Prosecution Office have shown that undeclared corporate donations - the infamous "box 02 (caixa 02)" - also supply electoral campaigns in Brazil. Such hidden donations disguise the link between donor and recipient, and can involve repayment for advantages ceded to the firms in 
02. This financing originates mainly from large firms and business groups. In the 2010 elections, more than 19,000 companies made electoral donations, but the 70 largest donors alone accounted for half of donations (MANCUSO and FERRAZ, 2012).

03. Such financial support can distort democratic values, such as political competition (by benefitting the best-funded candidates) and political equality (by giving an advantage to the largest financiers).

04. Financial support can also encourage illicit bargaining between the financiers and the financed (MANCUSO, 2015; PRZEWORSKI, 2011; SPECK, 2007; SPECK and PFEIFFER, 2007).

For these reasons, in 2015 the Supreme Court (Supremo Tribunal Federal, STF) prohibited corporate financing of campaigns. Nonetheless, the Constitutional Amendment Proposal on political reform (PEC 182/07), approved by the Chamber of Deputies and now being debated in the Federal Senate (PEC 113-A/15), defends the reinstatement of this form of financing. The question is far from resolved.

In the 2010 elections, corporate campaign backing was visible. Candidates hoped that these campaign resources could increase their chances of electoral success (FIGUEIREDO FILHO, 2009; HEILER, 2011; LEMOS, SILVA e PEDERIVA, 2010; MANCUSO, 2012; MANCUSO e SPECK, 2012; SILVA, 2010; PEIXOTO, 2010; SAMUELS, 2001a, 2002). The electoral system for the Chamber of Deputies in Brazil is that of openlist proportional representation, in which the voters can cast ballots for a political party or for a candidate presented by a party or by a coalition of parties ${ }^{4}$. This system induces the candidates to compete not only against rivals from other parties, but also against members of their own coalition (CAREY and SHUGART, 1995; SAMUELS, 2001b). Wellfinanced electoral campaigns are one way for candidates to distinguish themselves and increase their chances of victory.

This study responds to a central question: what was the profile of the 2010 candidates for federal deputy whose campaigns most depended on corporate donations ${ }^{5}$ ? Our main objective is to identify factors that help explaining the level of corporate dependence among them. In order to achieve this goal, this article is divided

the past, or promises of future advantages. Due to the character of these transfers, it is not possible to estimate the volume of the corporate 'caixa 02' in the different individual campaigns. ${ }^{4}$ The same system is valid in the elections for state-level legislative assemblies and city councils. ${ }^{5}$ In this article, we do not include the data on the 2014 election because, when the original version was drafted, the information on this election was not yet consolidated. 
into three sections and an introduction. The next part details the hypotheses and the methodology. The third presents the results. The last contains the conclusions.

\section{Hypotheses and methodology ${ }^{6}$}

This paper follows the recommendations of King (1995) with regard to the replicability of research results. For King, Keohane and Verba (1994), "all data and analyses should, insofar as possible, be replicable. Replicability applies not only to the data, so that we can see whether our measures are reliable, but to the entire reasoning process used in producing conclusions" (KING, KEOHANE and VERBA, 1994, p. 26). Chart 01 summarizes the principal characteristics of our research design.

Chart 01. Research design

\begin{tabular}{ll}
\hline Population & Federal Deputy candidates in 2010 \\
Variables & DV: Corporate dependence \\
IVs: Ideology, coalition, incumbency, occupation and gender \\
Hypotheses & H1: candidates of right-wing parties are more dependent on \\
corporate donations than candidates of the left. \\
H2: government coalition candidates are more dependent on \\
corporate donations than candidates from the opposition. \\
H3: incumbents are more dependent on corporate contributions \\
than challengers. \\
H4: candidates that are businesspeople are more dependent on \\
corporate donations than others. \\
H5: male candidates are more dependent on corporate donations \\
than female candidates. \\
Descriptive statistics, Pearson linear correlation, t-test, analysis \\
of variance (ANOVA), ordinary least squares linear regression \\
(OLS), cluster analysis and the Tobit model.
\end{tabular}

The dependent variable is "corporate dependence", defined as the proportion of campaign donations provided by business received directly by each candidate. Thus, if the campaign donations of candidate $X$ total $R \$ 1,000,000.00$ of which $\mathrm{R} \$ 100,000.00$ is provided directly by firms, the corporate dependence of this candidacy is $10 \%$. If candidate $\mathrm{Y}$ has the same amount of campaign donations, but receives $\mathrm{R} \$ 900,000.00$ from business, the corporate dependency is $90 \%$. Corporate dependence indicates how much a candidate needs corporate resources in his or her campaign. The variable shows not only whether or not the candidate received corporate finance, but also the extent to which the candidate depends on resources

${ }^{6}$ Raw data used in this article are available at: (01) http://www.tse.jus.br/eleicoes/repositoriode-dados-eleitorais and (02) http://dvn.iq.harvard.edu/dvn/dv/zucco. 
of this type, vis-à-vis resources from other sources. The underlying idea is that greater dependence on corporate support indicates a closer relationship between the candidate and business ${ }^{7}$.

The study of corporate dependence falls within the framework of research on campaign financing in Brazil. In Brazil there are three principal strands of study of electoral financing (MANCUSO, 2015). The first focuses on the effect of money on candidates' performance at the ballot box. The second examines the extent to which donations influence the political decisions taken by elected officeholders. The third strand, to which this present work is related, studies the determinants of electoral contributions. In this area, efforts are devoted to identifying and explaining the factors that are related to the campaign funds that are received by the candidates. Therefore, the objective of this article is to highlight factors that are connected to the importance of business money for different candidacies.

However, the study of corporate dependence - and its determinants - can raise questions that generate new research into the other two strands. For example, is corporate dependence connected to electoral success? If so, could the decision by the STF to ban corporate financing harm candidates who tend to rely more on business contributions? Or are such candidates also adept at obtaining resources from other legal sources - thereby counterbalancing the effect of the end of campaign financing by firms? In terms of the behavior of elected candidates, is the level of corporate dependence a determining factor in, for instance, bills proposed, opinions published and votes cast? Are other influence mechanisms such as lobbying equally important? For these reasons, it is argued here that the study of corporate dependence is of intrinsic importance, but can also fertilize other fields of study of campaign finance.

The independent variables focused upon in the article are political ideology, the term of office, affiliation with a party that belongs to the governing coalition in Congress, occupation and gender ${ }^{8}$.

\footnotetext{
${ }^{7}$ In this study, we do not distinguish between the candidates according to the amount of funds that they receive in total and from business. We intend to consider these difference in other articles.

${ }^{8}$ A BPSR anonymous reviewer suggested that corporate dependence could also be affected by two other factors: (i) affiliation with a party that belongs to the governing coalition in the states and (ii) the size of parties. Both hypotheses seem plausible and could be examined in future
} 
The first hypothesis is that the candidates from parties of the right are more dependent on corporate contributions than are candidates of parties of the left. This hypothesis is justified by the fact that parties of the left tend to be skeptical of corporate activities, and more supportive of state intervention in the economy. The scarcity of corporate donations to parties of the left in Brazil, in comparison with parties of other ideological stripes, has been noted by Samuels (2001a), Ribeiro (2006), Speck (2011) and Mancuso (2012). To measure the ideology of the parties, we use estimates from Zucco Jr. and Lauderdale (2011).

The second hypothesis is that the candidates of parties that belong to the congressional supporters of the president are more dependent on corporate donations than those who do not. Firms may prefer financing candidacies from governing coalition in order to strengthen their links with parties that are in power. Moreover, when the presiding government is popular among the electorate, as was the government of Lula da Silva, firms prefer candidates that belong to the government coalition due to an intention to maximize the success of any investment made, as they may believe that the chances of success for these candidates are greater. The positive association between membership of the coalition and campaign finance has been highlighted by Samuels (2001a), Lemos, Silva and Pederiva (2010), Mezzarana (2011) and Mancuso (2012). For membership of the governing coalition, we use again the data of Zucco Jr. and Lauderdale (2011).

Our third hypothesis is that incumbents are more dependent on contributions from businesses than challengers are. Incumbents are the candidates elected to the Chamber of Deputies in the 2006 election and who fought for reelection in 2010. There are two reasons for this hypothesis. One reason is that it is probable that the flow of donations is greater to incumbents because contributing firms know more about their past voting record. Firms may find it safer to invest in candidates that they know well. The second reason is that businesses may prefer incumbents who have already proven their political capital. Betting on the incumbents, firms may hope to make the most of their electoral investment. Moreover, studies have found a positive association between incumbency and electoral finance in previous elections to the Chamber of Deputies in Brazil (LEMOS,

work. Unfortunately, at this moment, the data that would permit us to test them are not available.

(2016) $10(3) \quad$ - $\quad 0004-6 / 24$ 
SILVA e PEDERIVA, 2010; MANCUSO, 2012; SILVA, 2010).

The fourth hypothesis is that candidates who are businesspeople are more dependent on corporate donations than are candidates who are not. We identify businesspeople as those who declare at least one of the following occupations to the Justiça Eleitoral: merchant, company director, entrepreneur, industrialist, rancher or agricultural producer. It seems reasonable to suppose that businesses prefer to finance the campaigns of candidates who are businesspeople for seeing them as "natural" representatives of their interests.

Finally, male candidates are hypothesized to be more dependent on corporate donations than female candidates. This is not only because Brazil's political scene is male-dominated, but also because the literature has noted the preference of companies for financing male candidates to the detriment of female candidates (SACCHET and SPECK, 2011).

\section{Results}

Table 01 shows, for all 27 parties that fielded candidates for federal deputy in the Brazilian elections of 2010, the absolute number and the percentage of candidates that received some type of electoral donation directly from businesses. The small parties of the extreme left, such as PCO - Partido da Causa Operária (Workers' Cause Party), PSTU - Partido Socialista dos Trabalhadores Unificado (Unified Workers' Socialist Party), PCB - Partido Comunista Brasileiro (Brazilian Communist Party) and PSOL - Partido Socialismo e Liberdade (Socialism and Freedom Party), have the smallest percentage of candidates financed directly by firms. This percentage reaches highest values in some of the major political parties, such as PT - Partido dos Trabalhadores (Workers' Party), DEM - Democratas (Democrats), PR - Partido da República (Party of the Republic), PP - Partido Progressista (Progressive Party), PSDB - Partido da Social Democracia Brasileira (Brazilian Social Democracy Party), and PMDB - Partido do Movimento Democrático Brasileiro (Brazilian Democratic Movement Party). This research studies only the 1,759 candidacies, from 25 political parties, that declared to the Justiça Eleitoral that they directly received some contribution from businesses. 
Table 01. Candidates that received donations from businesses, by party

\begin{tabular}{|c|c|c|c|c|c|}
\hline \multirow{2}{*}{ Party } & \multicolumn{4}{|c|}{ Did the candidate receive a corporate donation? } & \multirow{2}{*}{ Tota } \\
\hline & No & $\%$ & Yes & $\%$ & \\
\hline PCO & 7 & 100.0 & 0 & 0.0 & 7 \\
\hline PSTU & 30 & 100.0 & 0 & 0.0 & 30 \\
\hline PCB & 15 & 88.2 & 2 & 11.8 & 17 \\
\hline PSOL & 179 & 84.8 & 32 & 15.2 & 211 \\
\hline PT do B & 84 & 81.6 & 19 & 18.4 & 103 \\
\hline PTC & 174 & 80.9 & 41 & 19.1 & 215 \\
\hline PMN & 144 & 80.4 & 35 & 19.6 & 179 \\
\hline PRP & 66 & 79.5 & 17 & 20.5 & 83 \\
\hline PHS & 117 & 78.0 & 33 & 22.0 & 150 \\
\hline PTN & 67 & 77.9 & 19 & 22.1 & 86 \\
\hline PSL & 102 & 77.9 & 29 & 22.1 & 131 \\
\hline PRB & 89 & 76.1 & 28 & 23.9 & 117 \\
\hline PRTB & 74 & 74.7 & 25 & 25.3 & 99 \\
\hline PSDC & 44 & 74.6 & 15 & 25.4 & 59 \\
\hline PSC & 115 & 64.6 & 63 & 35.4 & 178 \\
\hline PV & 179 & 58.5 & 127 & 41.5 & 306 \\
\hline PPS & 74 & 57.8 & 54 & 42.2 & 128 \\
\hline PTB & 148 & 57.1 & 111 & 42.9 & 259 \\
\hline PSB & 150 & 56.2 & 117 & 43.8 & 267 \\
\hline PDT & 137 & 55.7 & 109 & 44.3 & 246 \\
\hline PC do B & 60 & 52.6 & 54 & 47.4 & 114 \\
\hline PMDB & 148 & 45.0 & 181 & 55.0 & 329 \\
\hline PSDB & 106 & 43.6 & 137 & 56.4 & 243 \\
\hline PP & 75 & 39.9 & 113 & 60.1 & 188 \\
\hline PR & 54 & 38.6 & 86 & 61.4 & 140 \\
\hline DEM & 65 & 37.8 & 107 & 62.2 & 172 \\
\hline PT & 107 & 34.3 & 205 & 65.7 & 312 \\
\hline TOTAL & 2,61 & 59.7 & 1,759 & 40.3 & 4,369 \\
\hline
\end{tabular}

Source: Tribunal Superior Eleitoral, TSE data.

Note: See the list of Brazilian parties on the Appendix 2.

Graph 01. Histogram of the distribution of the dependent variable

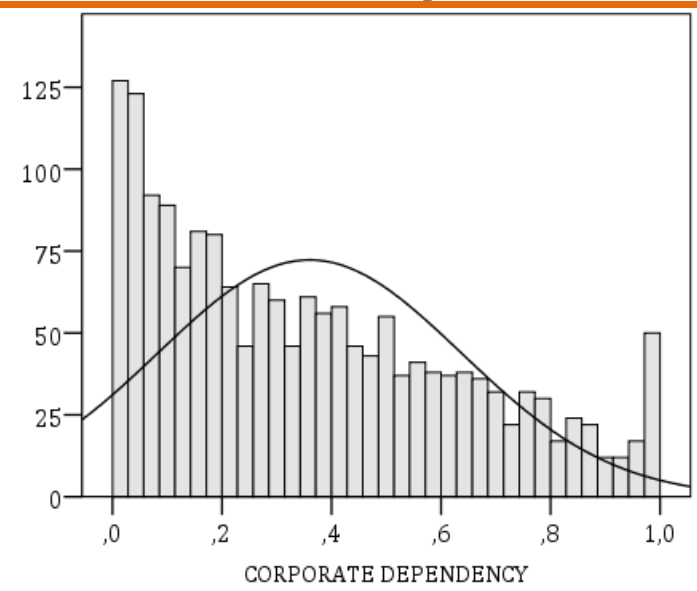

Source: Tribunal Superior Eleitoral, TSE data.

Notes: $\mathrm{n}=1,759 /$ Mean $=35.99 \% / \mathrm{SD}=27.33 \%$
(2016) 10 (3)
$\mathrm{e} 0004-8 / 24$ 
The histogram illustrates the frequency distribution of the proportion of corporate contributions for the candidates to the Chamber of Deputies. It is worth noting that the mean corporate dependence is $35.99 \%$ with a standard deviation of $27.73 \%$ for the 1,759 cases analyzed. Graph 02 shows the dependency on corporate donations by party.

Graph 02. Corporate contributions by party (decreasing)

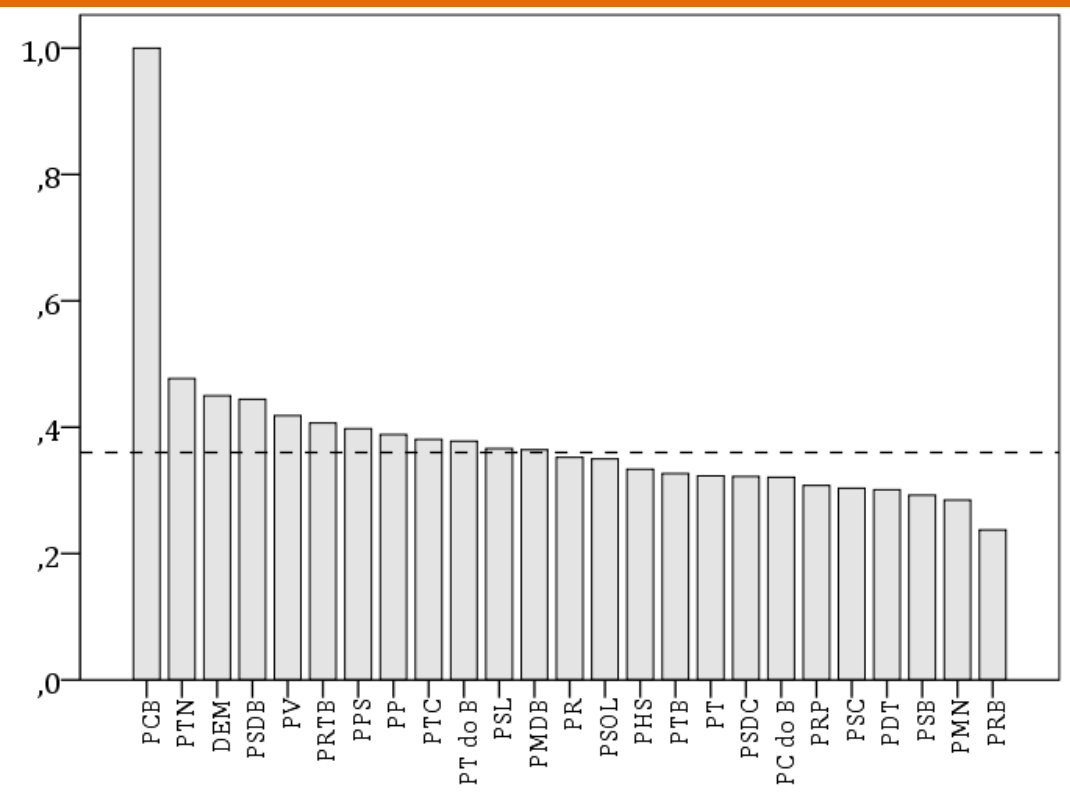

Source: Tribunal Superior Eleitoral, TSE data.

Note: See the list of Brazilian parties on the Appendix 2.

The dashed line represents the mean corporate dependence (35.99\%). The few candidates of the PCB that received business donations received $100 \%$ of their donations from corporate sources. The candidates of the PTN appear in second place (48\%), followed by those of the DEM (45\%) and the PSDB (44\%). At the other end, candidates of the PSB (29\%), the PMN (28\%) and the PRB (24\%) are less dependent on corporate contributions. Graph 03 illustrates the distribution of the parties on two different dimensions: mean revenue invested in the campaign and percentage of corporate contributions. 
Graph 03. Average revenue and percentage of corporate contributions by party (Z) with and without outliers
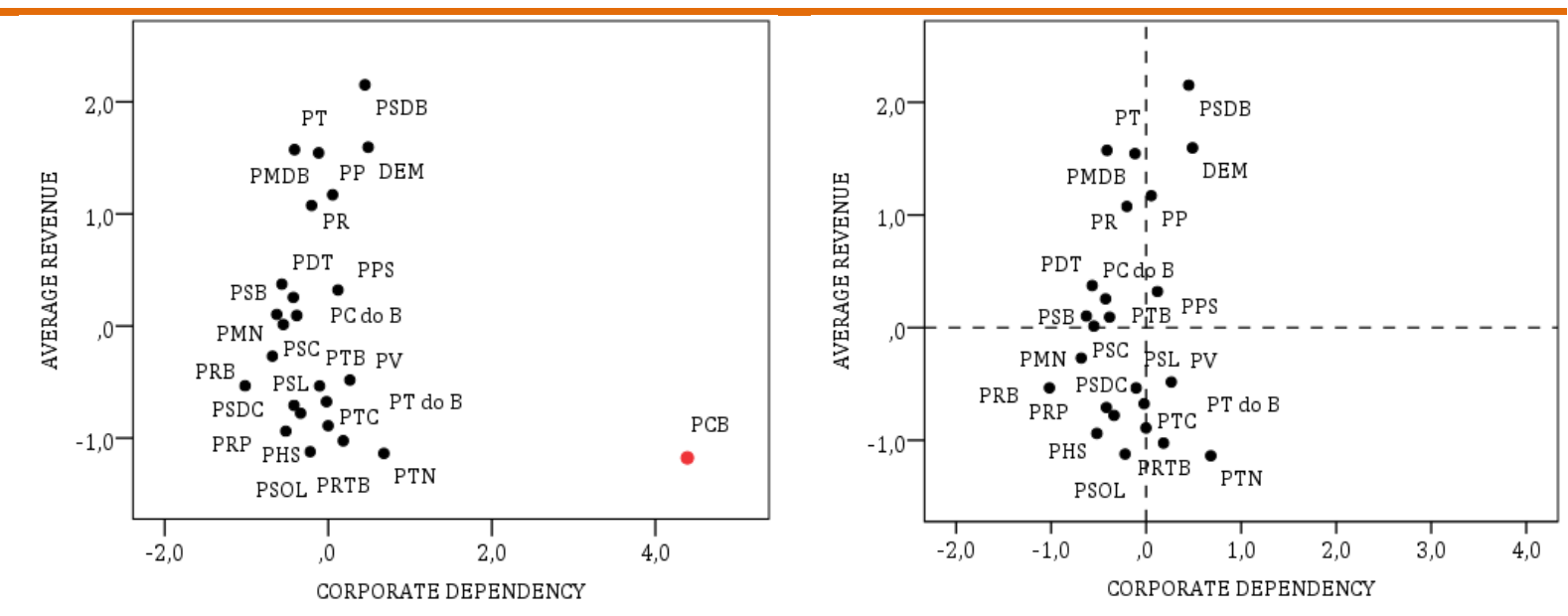

Source: Tribunal Superior Eleitoral, TSE data.

Note: See the list of Brazilian parties on the Appendix 2.

The variables were standardized to set the mean at zero and the standard deviation at one. The PCB candidates exhibit a pattern that is quite different from that of candidates of other parties (see left-side screen of Graph 3), corroborating the information presented in Graph 02. We also show a figure without these outliers. The right-side screen of Graph 03 shows that the candidates of the PSDB and the DEM not only invest more resources in their campaigns, but are also more dependent on corporate contributions. PT candidates are also well financed, but less dependent on corporate funding. The candidates of the PTN have the opposite profile: they are less financed, yet still heavily dependent on business donations. The PRB, PSDC and PRP are noteworthy as parties whose candidates possess fewer resources and show less corporate dependence.

After this descriptive analysis of our dependent variable, the next step is to examine how it varies in relation to the independent variables. Table 02 classifies the parties by ideology, membership in the presidential coalition in the Chamber, the percentage of incumbents and mean corporate dependence. In order to categorize the parties along an ideological spectrum, we used cluster analysis to create three clusters (left, center and right) from the estimates produced by Zucco Jr. and Lauderdale $(2011)^{9}$.

${ }_{9}$ In Zucco Jr. and Lauderdale (2011), "political ideology" is a continuous variable. The larger its value, more right-wing is the party. Initially, we used the K-Means Cluster method, with $\mathrm{K}=3$. We 
Table 02. Ideology, coalition, incumbents and corporate dependency, by party

\begin{tabular}{lcccc}
\hline Party & Ideology & Coalition & Incumbents (\%) & Corporate Dependency (\%) \\
\hline DEM & Right & No & 36.4 & 44.98 \\
PCDOB & Left & Yes & 18.5 & 32.08 \\
PDT & Center & Yes & 17.4 & 30.09 \\
PMDB & Center & Yes & 35.4 & 36.44 \\
PP & Right & Yes & 31.0 & 38.85 \\
PPS & Center & No & 16.7 & 39.78 \\
PR & Right & Yes & 40.7 & 35.23 \\
PSB & Left & Yes & 21.4 & 29.22 \\
PSDB & Center & No & 34.3 & 44.42 \\
PSOL & Left & No & 6.2 & 34.98 \\
PT & Left & Yes & 32.7 & 32.29 \\
PTB & Right & Yes & 15.3 & 32.67 \\
PV & Center & No & 7.1 & 41.83 \\
\hline
\end{tabular}

Sources: Tribunal Superior Eleitoral, TSE and Zucco Jr. and Lauderdale (2011) data.

Note: See the list of Brazilian parties on the Appendix 2.

Graph 04 depicts the correlation between ideology and corporate contributions $(\%)$. There is a statistically significant $(\mathrm{p}$-value $<0.09)$ and positive correlation $(\mathrm{r}=$ 0.488) between them. In other words, on average, the more right-wing a party is, the greater the corporate dependence of its candidates.

Graph 04. Correlation between ideology and corporate dependence (\%)

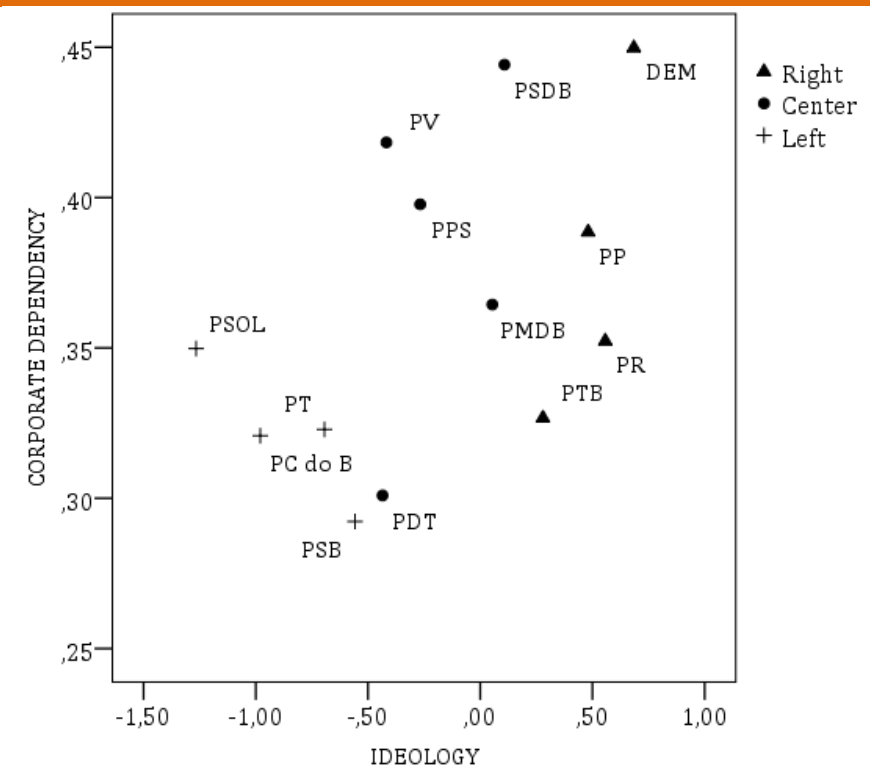

Sources: Tribunal Superior Eleitoral, TSE and Zucco Jr. and Lauderdale (2011) data. Note: See the list of Brazilian parties on the Appendix 2.

adopted 10 as the maximum number of iterations and the model converged after the fourth iteration. To guarantee more robust results, we repeated the analysis using the hierarchical grouping method. As a measure of distance, we used squared Euclidean distance. Both solutions produced very similar results. 
Graph 05 illustrates the mean of corporate dependence by ideology. The candidates of right-wing parties $(\bar{X}=38 \%$; sd $=26.81 ; \mathrm{n}=417)$ and center $(\bar{X}=39 \%$; $\mathrm{sd}=$ 28.89; $n=608$ ) display very similar means. Candidates of the left have a mean of $32 \%$, with a standard deviation of 25,15 and a total of 408 cases. The analysis of variance (ANOVA) suggests that at least one of the groups is significantly different from the others $(\mathrm{F}=8.926$ and $\mathrm{p}$-value $<0.000)$. Table 03 compares these by pair ${ }^{\mathbf{1 0}}$.

Graph 05. Corporate dependence by ideology (CI 95\%)

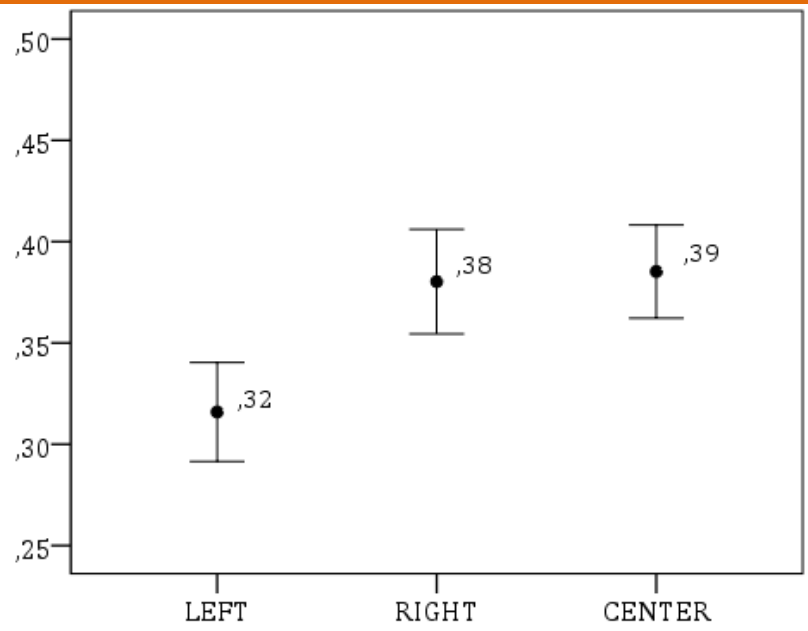

Source: Tribunal Superior Eleitoral, TSE and Zucco Jr. and Lauderdale (2011) data.

Table 03. Multiple comparisons (\%)

\begin{tabular}{llrrrr}
\hline \multicolumn{2}{c}{ Ideology } & Diff. (I-J) & p-value & Lower & CI 95\% \\
$(\mathrm{I})$ & $(\mathrm{J})$ & -0.00 & 0.958 & -0.05 & 0.04 \\
\hline Right & Center & 0.06 & 0.001 & 0.02 & 0.11 \\
Left & & 0.00 & 0.958 & -0.04 & 0.05 \\
Center & Right & 0.07 & 0.000 & 0.03 & 0.11 \\
Left & & &
\end{tabular}

Source: Tribunal Superior Eleitoral, TSE and Zucco Jr. and Lauderdale (2011) data.

The comparison corroborates the data presented in graph 05: there is no significant difference between right and center candidates (Diff. $=-0.00 ; p$-value $=0.958$ ). In the right versus left comparison, the mean difference is $06 \%$ (p-value $<0.001$ ). Lastly, comparing candidates of parties of the center with parties of the left, we observe once more a statistically significant difference (Diff. $=0.07$; p-value $<0.000$ ). In summary, the

${ }^{10}$ Initially we used Tukey's test, assuming equal variance between the groups. However, the Levene test indicated that the groups have different variance. For this reason, we present here the results of Games-Howell's test. 
bivariate analysis presented above is favorable to hypothesis 01: candidates of the right are more dependent on corporate donations than those of the Left. However, these partial findings permit us to say more: they show that right and center candidates display a similar pattern in terms of corporate financing, and both differ significantly from candidates of the left.

After analyzing how the percentage of corporate contributions varies by party ideology, the next stage is to examine this variation for parties of the government coalition, in relation to parties of the opposition. To classify parties by government support, we use again the estimates by Zucco Jr. and Lauderdale (2011) ${ }^{11}$. Graph 06 depicts the correlation between government support and corporate contributions (\%).

Graph 06. Correlation between government support and corporate contributions (\%)

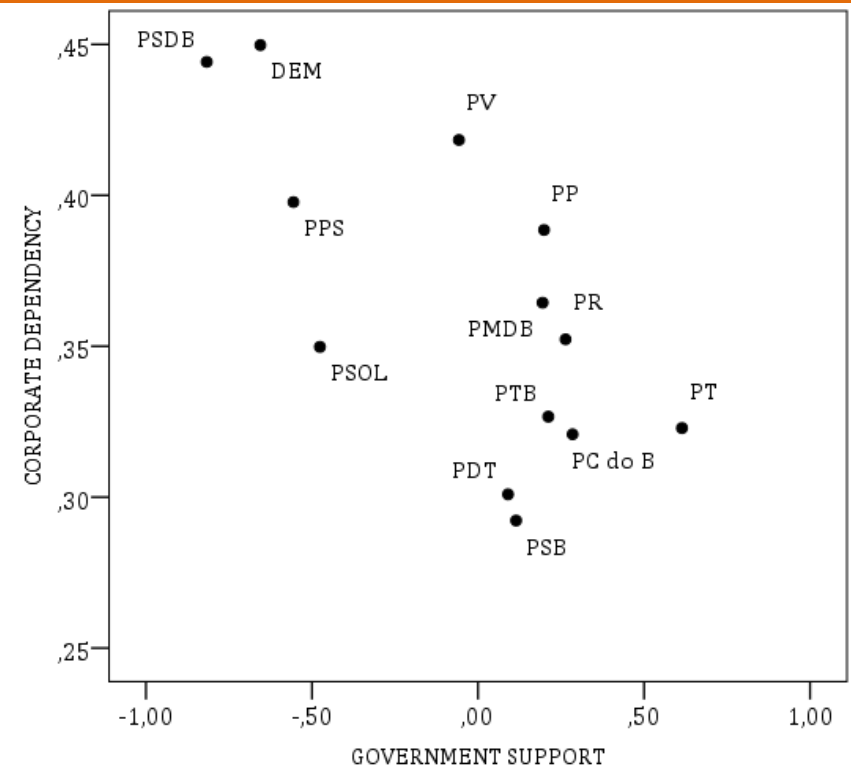

Sources: Tribunal Superior Eleitoral, TSE and Zucco Jr. and Lauderdale (2011) data. Note: See the list of Brazilian parties on the Appendix 2.

There is a negative correlation (-0.710), which is statistically significant (pvalue $<0.007$ ) between being a member of the governing coalition and the percentage of business contributions $(n=13)$. This means that, on average, parties that form part of the governing coalition are less dependent on corporate donations than the parties of the opposition are. Graph 07 compares the distribution of corporate dependence between candidates of the government coalition and opposition parties.

11 Parties with negative indices of "government support" were considered as the opposition and parties with positive indices as members of the coalition. 
Graph 07. Corporate dependence: governing coalition and opposition (\%) (CI 95\%)

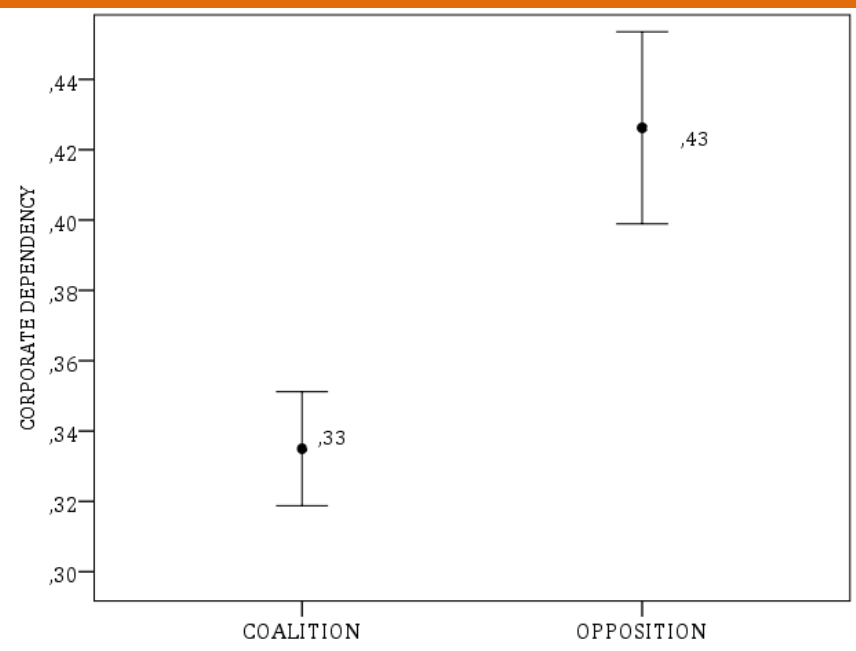

Sources: Tribunal Superior Eleitoral, TSE and Zucco Jr. and Lauderdale (2011) data.

Opposition party candidates $(\bar{X}=43 \%$; sd $=29.71 ; \mathrm{n}=457)$ are more dependent on corporate donations than candidates of parties that make up the coalition $(\bar{X}=33 \%$; $s d=25.78 ; n=976)$. The $\mathrm{t}$-test suggests that the mean difference of $9.92 \%$ between the two groups is statistically significant $(t=-5.645$; $p$-value $<0.000)$. In other words, the partial results obtained in the bivariate analysis do not support hypothesis 02 . Actually, they point to the opposite conclusion: corporate donations are comparatively more important for opposition candidates than for government-allied ones.

The next step is to examine the difference between incumbents and challengers. Graph 08 compares the distribution of corporate contributions by candidate type.

Graph 08. Corporate dependence by candidate type (CI 95\%)

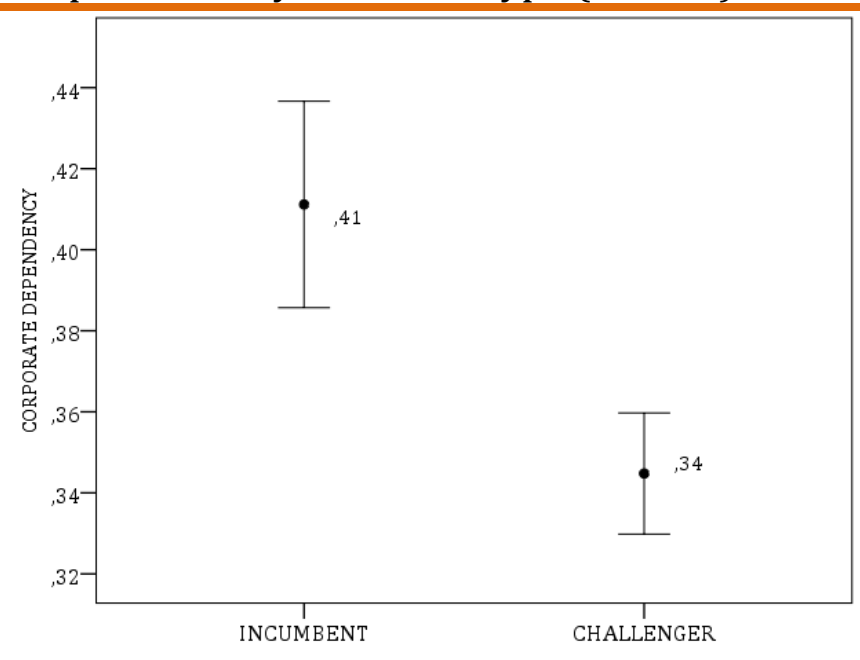

Source: Tribunal Superior Eleitoral, TSE data. 
On average, incumbents $(\bar{X}=41 \%$; sd $=25.98 ; \mathrm{n}=402)$ are more dependent on corporate resources than challengers $(\bar{X}=34 \%$; $\mathrm{sd}=28.06 ; \mathrm{n}=1,357)$. The mean difference between the groups is statistically significant $(t=4.236$ and $p$-value $<0.000)$. Therefore, the results of the bivariate analysis support hypothesis 03 , showing that the candidates for reelection develop stronger ties with the business world than challengers, in terms of campaign support.

We now examine if there is a significant difference in terms of corporate dependency between candidates who are from the business world and those who are not.

Graph 09. Corporate dependence by occupation (CI 95\%)

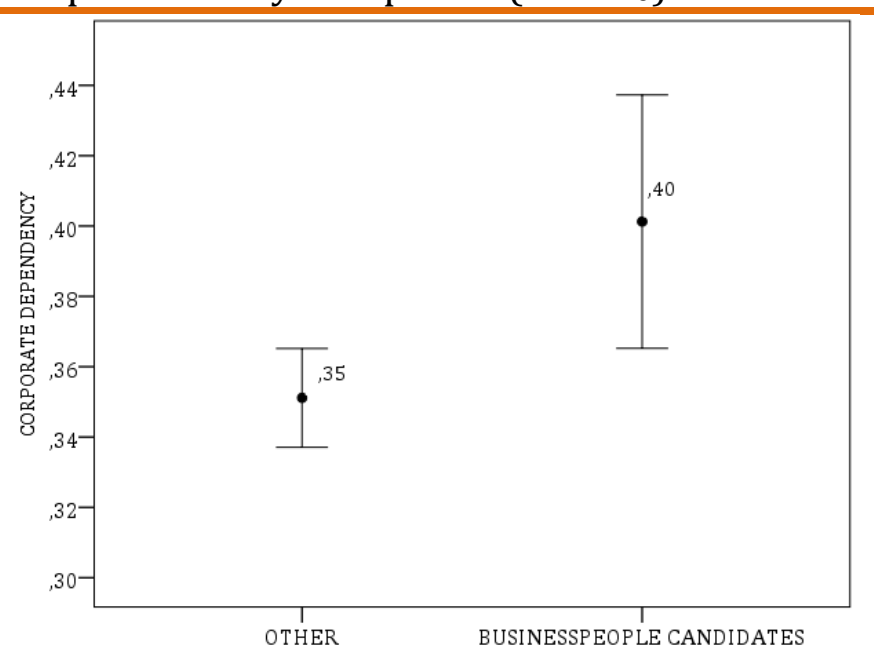

Source: Tribunal Superior Eleitoral, TSE data.

It is possible to see that, on average, businesspeople candidates $(\bar{X}=40 \%$; $\mathrm{sd}=$ 29.83; $\mathrm{n}=266)$ are more dependent on corporate resources than other candidates $(\bar{X}=$ $35 \%$; $s d=27.16 ; n=1,439$ ). The t-test indicates that the null hypothesis of equality in the means of the two groups can be rejected $(t=-2.551$ and $p$-value $<0.011)$. In other words, supporting hypothesis 04 , the bivariate analysis suggests that the importance of corporate donations is greater for the candidates that are businesspeople than those who are not.

Finally, we compare corporate dependence between male and female candidates. Graph 10 illustrates the means. 
Graph 10. Corporate dependence by gender (CI 95\%)

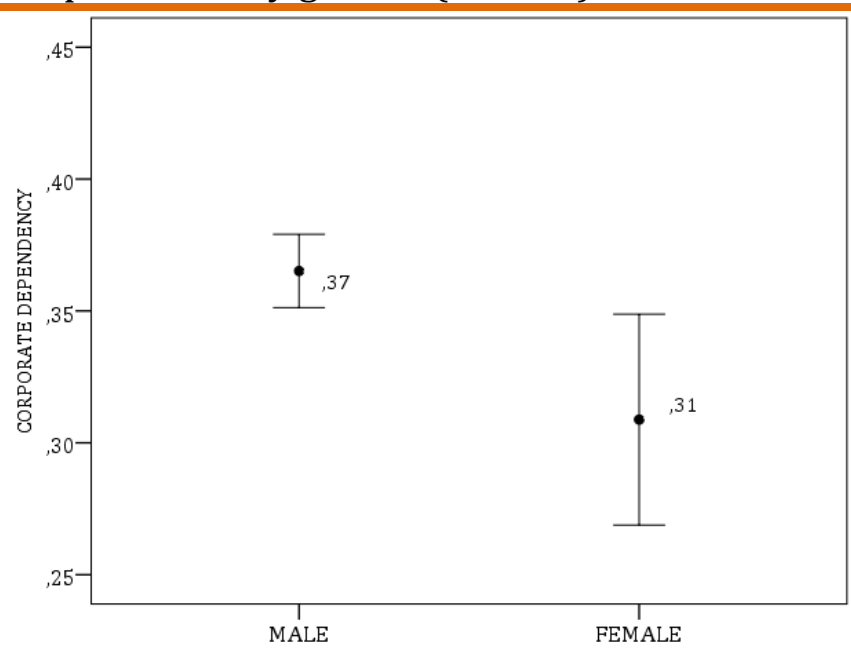

Source: Tribunal Superior Eleitoral, TSE data.

It is worth noting that the male candidates $(\bar{X}=37 \%$; $\mathrm{sd}=27.59 ; \mathrm{n}=1,518)$ possess greater corporate dependence than the female candidates $(\bar{X}=31 \%$; sd $=$ $27.70 ; \mathrm{n}=187)$ and that the difference is statistically significant $(\mathrm{t}=2.634$ and $\mathrm{p}$ value<0.009). In the bivariate analysis, however, the gender variable appears correlated with the dependence on corporate election resources, as predicted by hypothesis 05 .

Following bivariate analyses, we estimate a multivariate model to explain the level of corporate dependence of the candidates, controlling the effect of each factor by the effect of the others ${ }^{12}$. Table 04 displays the results ${ }^{13}$.

12 With the objective of producing more reliable results, we tested this model with other functional forms. This option is justifiable because the dependent variable does not follow a normal distribution. Thus, the estimates produced by the ordinary least squares method are not the best linear unbiased estimates of population parameters. Although the Central Limit Theorem shows that the sampling distribution of estimates follows a normal distribution when there is a large number of cases, we ran these tests, which may be found in the Appendix 01. ${ }^{13}$ Zucco Jr. and Lauderdale (2011) produced estimates for the following parties: DEM, PC do B, PDT, PMDB, PP, PPS, PR, PSB, PSDB, PSOL, PT, PTB and PV. As two of our independent variables are derived from these estimates, our multivariate model is limited to candidates of these parties. In this work we opt for highlighting the sign and significance of the coefficients estimated. The $\mathrm{R}^{2}$ of this model was 0.056 . This value indicates that the fit of this model is limited and could be improved in this sense. 
Table 04. Multivariate model (OLS)

\begin{tabular}{lc}
\hline Variables & Coefficient \\
\hline \multirow{2}{*}{ Right } & $0.045^{*}$ \\
& $(0.019)$ \\
Center & 0.030 \\
& $(0.019)$ \\
Coalition & $-0.089^{* * *}$ \\
& $(0.017)$ \\
Incumbent & $0.089^{* * *}$ \\
Businessperson & $0.016)$ \\
Gender & $0.044^{*}$ \\
& $(0.021)$ \\
Constant & -0.033 \\
\end{tabular}

Source: Tribunal Superior Eleitoral, TSE data.

Notes: ${ }^{*}=P \leq 0.05 ;{ }^{* *}=P \leq 0.01 ;{ }^{* * *}=P \leq 0.001 / \mathrm{N}=1,404 ; \mathrm{R}^{2}=0.056 ;$ Adjusted $\mathrm{R}^{2}=0.052$

It is possible to confirm that the ideology of a candidate is connected to the degree of corporate dependence, even when controlling for the effect of the other variables. The candidates of right-leaning parties have a greater corporate dependence than those of the left, confirming hypothesis 01 . Such a difference is probably a result of mechanisms that operate as much on the supply side as on the demand side. On the supply-side, it is possible that firms are more disposed to finance candidates favorable to free trade and lesser state intervention in the economy. On the demand-side, it is plausible that right-wing candidates are more likely to seek in the corporate world allies favorable to investing in their campaigns. In contrast to what we observed in the bivariate analysis, the multivariate analysis does not display statistically significant differences between candidates of the center and the left with respect to corporate dependence.

In addition, the membership of the party in the government coalition in Congress is linked to the corporate dependence of its candidates, but in a way that is contrary to the initial hypothesis. On average, the level of corporate dependence of candidates of the parties of the opposition is significantly greater than is that of the candidates of the governing coalition. This result holds when we use the classification of the Legislative Dataset of CEBRAP to measure the membership of a party to the government coalition ${ }^{14}$. This can be explained by table 02 and graph 04 , which show the

14 We thank Fernando Limongi for access to this dataset.

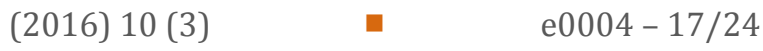


high degree of corporate dependence among the candidates of the PSDB and DEM, both being the principal opposition parties under the Lula government. The literature mentioned in this article, which suggests a positive relation between belonging to the coalition and electoral financing (not only electoral financing by firms), has focused on the elections of 1994 (LEMOS, SILVA and PEDERIVA, 2010; MANCUSO, 2012; MEZZARANA, 2011; SAMUELS, 2001a, 2001b and 2002). A more detailed comparison between the election of 2010 and the previous elections could reveal more about these differences.

There is strong evidence that, on average, the incumbent candidates are more dependent on corporate funding than challengers are. The result suggests that in the terminology of McMenamin $(2009,2012)$, ideological and pragmatic factors probably coexist in business' decision of whom to support financially, and in candidates' decisions about where to seek funds for their campaigns. Firms direct their resources not only to candidates who are ideologically closer to themselves, but also, in pragmatic fashion, toward candidates whose electoral viability has been previously tested. The available data do not permit us to conclude whether the pragmatic option for incumbent candidates up for re-election is motivated by reciprocity for past favors. In turn, incumbents up for re-election appear to have easier access to the business world than their challengers do.

It is also possible that a candidate's identity as a businessperson is associated with a greater level of corporate dependence. This may be due to the preference of businesspeople to finance each other, in the expectation that, if elected, they will defend their shared interests. Another possible explanation is that business candidates use donations from their own companies to finance their campaigns, hence increasing observed corporate dependence.

Finally, in the multivariate analysis, there is no evidence that male candidates are more dependent on corporate funds than female candidates are ${ }^{15}$. When the effect of the other variables is taken into account, the association between gender and corporate dependency disappears.

15 The conclusions detailed above largely hold also when candidates for federal deputy who received no business donations are included (see Appendix 01). When these candidates are included, the gender variable becomes significant in the direction posited by our hypothesis. 


\section{Conclusion}

The results of this study partially confirm our initial hypotheses. There is evidence in favor of three of them: candidates of right-wing parties have a greater corporate dependence than those of the left, incumbents have greater corporate dependence than challengers and candidates who are businesspeople receive more donations from the business world than candidates who are not. One hypothesis was clearly rejected: candidates belonging to the government coalition are more dependent on corporate funding than those in the opposition parties. In truth, the results demonstrate that candidates of opposition parties receive more generous corporate funding. Moreover, there was no evidence to support the hypothesis that among men corporate dependence is greater than among women. In sum, we can state that the candidates for federal deputy whose campaigns depend more on corporate donations belong to the right, are part of the opposition bloc in the Chamber of Deputies, are already serving in the House and work in the business world. Being male or female apparently does not affect dependence on business resources. It is worth emphasizing that the scope of these findings is limited to the 2010 elections for the Chamber of Deputies.

There are three directions for future research. The first is to consider the magnitude of funds that candidates receive (in total and from business), in order to verify if there is a common profile of those who receive greater electoral contributions from business. It is also worth extending this analysis to other elections to the Chamber of Deputies, as well as to proportional elections at the state and municipal levels. Finally, we hope to investigate the association of the independent variables identified in this study with another dependent variable of interest: "corporate concentration", i.e., the proportion of total business electoral contributions that is received by each candidate in his or her district. While 'corporate dependence' shows how much a candidate depends on business contributions to fund his campaign, 'corporate concentration' shows the extent to which companies concentrate their donations on just a few candidates. Corporate dependence and corporate concentration are different and complementary faces of the same phenomenon: the relation between the world of business and the world of politics in a political contest. 


\section{References}

CAREY, John M. and SHUGART, Matthew S. (1995), Incentives to cultivate a personal vote: a rank ordering of electoral formulas. Electoral Studies. Vol. 14. № 04, pp. 417439.

FIGUEIREDO FILHO, Dalson Brito (2009), O elo corporativo? Grupos de interesse, financiamento de campanha e regulação eleitoral. Master's dissertation. Programa de Pós-graduação em Ciência Política. UFPE.

HAGGARD, Stephan; SCHNEIDER, Ben Ross, and MAXFIELD, Sylvia (1997), Theories of business and business-state relations. In: Business and the state in developing countries. Edited by MAXFIELD, Sylvia and SCHNEIDER, Ben Ross. Ithaca: Cornell University Press. pp. 36-60.

HEILER, Jeison G. (2011), Democracia: o jogo das incertezas x financiamento de campanhas: uma análise das prestações de contas das campanhas de Vereadores de SC. Paper presented at the 35을 ANPOCS Annual Meeting, Caxambu/MG.

KING, Gary (1995), Replication, replication. PS: Political Science and Politics. № 28, pp. 443-499.

KING, Gary; KEOHANE, Robert, and VERBA, Sidney (1994), Designing social inquiry. New Jersey: Princeton University Press. 264 pp..

LEMOS, Leany B.; SILVA, Daniel Marcelino da, and PEDERIVA, João Henrique (2010), Porque dinheiro importa: a dinâmica das contribuições eleitorais para o Congresso Nacional em 2002 e 2006. Opinião Pública. Vol. 16, № 02, pp. 366-393.

MANCUSO, Wagner Pralon (2012), Empresas e financiamento de campanhas eleitorais de candidatos a deputado federal pelo estado de São Paulo nas eleições de 2002 e 2006. In: Desenvolvimento e crise na América Latina: estado, empresas e sociedade. Edited by COSTA, Armando Dalla; MINELLA, Ary Cesar; GROS, Denise Barbosa; MICK, Jacques; ETCHEVERRY, Maria Soledad, and IGLECIAS, Wagner. Curitiba: Editora CRV. pp. 139-178.

MANCUSO, Wagner Pralon (2015), Investimento eleitoral no Brasil: balanço da literatura (2001-2012) e agenda de pesquisa. Revista de Sociologia e Política. Vol. 23, № 54, pp. 155-183.

MANCUSO, Wagner Pralon and FERRAZ, Alexandre Sampaio (2012), As distorções do financiamento de campanhas. Revista Fórum. № 108, pp. 20-21.

MANCUSO, Wagner Pralon; SPECK, Bruno W. (2012), Financiamento empresarial e desempenho eleitoral no Brasil: um estudo das eleições para deputado federal em

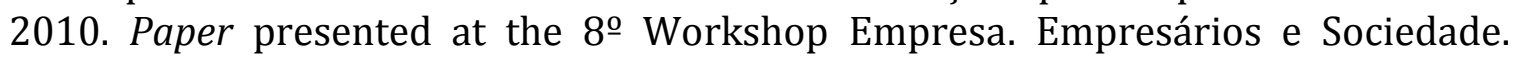
Curitiba. 
McMENAMIN, Iain (2009), The four logics of business, money, and political parties. In: Interest groups and lobbying in the United States and comparative perspectives. Edited by McGRATH, Conor. Lewiston: The Edwin Mellen Press. pp. 207-223.

McMENAMIN, Iain (2012), If money talks, what does it say?: varieties of capitalism and business financing of parties. World Politics. Vol. 64, № 01, pp. 01-38.

MEZZARANA, Flávia S. (2011), Poder econômico na política: a influência dos financiadores de campanha na atuação parlamentar. Undergraduate thesis. Management of Public Policies. EACH-USP. 124pp.

PEIXOTO, Vitor de M. (2010), Eleições e financiamento de campanhas no Brasil. Phd thesis. Instituto Universitário de Pesquisas do Rio de Janeiro.

PRZEWORSKI, Adam (2011), Money, politics, and democracy. Paper presented at a conference at the Department of Political Science, USP.

RIBEIRO, Renato Janine (2006), Financiamento de campanha (público versus privado). In: Reforma política no Brasil. Edited by AVRITZER, Leonardo and ANASTASIA, Fátima. Belo Horizonte: UFMG. Brasília: PNUD. pp. 77-81.

SACCHET, Teresa and SPECK, Bruno (2011), Partidos políticos e (sub)representação feminina nas esferas legislativas: um estudo sobre recrutamento eleitoral e financiamento de campanhas. Paper presented at the IPSA-ECPR Conference Whatever Happened to North-South?. São Paulo.

SAMUELS, David (2001a), Does money matter? Credible commitments and campaign finance in new democracies: theory and evidence from Brazil. Comparative Politics. Vol. 34, № 01, pp. 23-42.

SAMUELS, David (2001b), Money, elections, and democracy in Brazil. Latin American Politics and Society. Vol. 43, № 02, pp. 27-48.

SAMUELS, David (2002), Pork barreling is not credit claiming or advertising: campaign finance and the source of the personal vote in Brazil. The Journal of Politics. Vol. 64, № 03 , pp. 845-863.

SILVA, Daniel Marcelino (2010), Sobre dinheiro e eleições: um estudo dos gastos de campanha para o Congresso Nacional em 2002 e 2006. Master's dissertation. Universidade de Brasília.

SPECK, Bruno W. (2007), O financiamento de campanhas eleitorais. In: Reforma política no Brasil. Edited by AVRITZER, Leonardo and ANASTASIA, Fátima. Belo Horizonte: UFMG; Brasília: PNUD. pp. 153-158.

SPECK, Bruno W. (2011), Objetivos e estratégias do setor privado no financiamento das campanhas eleitorais: um modelo de análise baseado em dados da campanha eleitoral no Brasil em 2010. Paper presented at the IPSA-ECPR Conference Whatever Happened to North-South?, São Paulo/SP. 
SPECK, Bruno; PFEIFFER, Silke (2007), Introducción. In: El control ciudadano del financiamiento político: una guía práctica sobre experiencias y desafíos. Edited by SPECK, Bruno and PFEIFFER, Silke. Berlin: International Transparency. pp. 7-8.

ZUCCO JR., Cesar and LAUDERDALE, Benjamin E. (2011), Distinguishing between influences on Brazilian legislative behavior. Legislative Studies Quarterly. Vol. 36, № 03, pp. 363-396. 


\section{Appendix 1}

In order to produce more reliable results, we tested our model with other functional forms. Table 1.1 summarizes the estimated coefficients for models Gamma, Inverse Normal and Tobit.

Table 1.1. Models comparison (Gama, Inverse Normal and Tobit)

\begin{tabular}{llll}
\hline Variables & Gamma & Inverse Normal & Tobit \\
\hline \multirow{2}{*}{ Right } & $0.041^{*}$ & $0.039^{*}$ & $0.045^{*}$ \\
& $(0.018)$ & $(0.018)$ & $(0.019)$ \\
Center & 0.028 & 0.028 & 0.029 \\
& $(0.017)$ & $(0.017)$ & $(0.019)$ \\
Coalition & $-0.084^{* * *}$ & $-0.082^{* * *}$ & $-0.091^{* * *}$ \\
Incumbency & $(0.018)$ & $(0.019)$ & $(0.017)$ \\
& $0.084^{* * *}$ & $0.082^{* * *}$ & $0.088^{* * *}$ \\
Businessperson & $(0.018)$ & $(0.019)$ & $(0.016)$ \\
\multirow{3}{*}{ Gender } & 0.036 & 0.033 & $0.045^{*}$ \\
& $(0.022)$ & $(0.023)$ & $(0.023)$ \\
Constant & -0.032 & -0.031 & -0.032 \\
& $(0.020)$ & $(0.019)$ & $(0.023)$ \\
& $0.371^{* * *}$ & $0.371^{* * *}$ & $0.374^{* * *}$ \\
\hline
\end{tabular}

Tribunal Superior Eleitoral, TSE and Zucco Jr. and Lauderdale (2011) data.

Notes: $\mathrm{N}=1,404^{*}=P \leq 0.05 ;^{* *}=P \leq 0.01 ;{ }^{* * *}=P \leq 0.001$.

As mentioned in note 15, our conclusions largely hold when candidates for federal deputy who received no business donations are included in the model. The only difference is that the gender variable becomes significant in the direction posited by our hypothesis.

Tabela 1.2. Multivariate model for all candidates (OLS)

\begin{tabular}{ll} 
Variables & Normal \\
Right & $0.051^{* * *}$ \\
& $(0.013)$ \\
& $0.034^{* *}$ \\
Center & $(0.012)$ \\
& -0.020 \\
Coalition & $(0.011)$ \\
& $0.236^{* * *}$ \\
Incumbency & $0.014)$ \\
& $0.037^{*}$ \\
Businessperson & $(0.014)$ \\
& $-0.064^{* * *}$ \\
Gender & $(0.013)$ \\
& $0.371^{* * *}$ \\
Constant & $(0.021)$ \\
\hline
\end{tabular}

Tribunal Superior Eleitoral, TSE and Zucco Jr. and Lauderdale (2011) data.

Notes: ${ }^{*}=P \leq 0.05 ;{ }^{* *}=P \leq 0.01 ;{ }^{* *}=P \leq 0.001 / \mathrm{N}=2,759 \mathrm{R}^{2}=0.122$ Adjusted $\mathrm{R}^{2}=0.120$ 


\section{Appendix 2}

\section{List of Brazilian Parties}

PC do B - Partido Comunista do Brasil (Communist Party of Brazil)

PCB - Partido Comunista Brasileiro (Brazilian Communist Party)

PCO - Partido da Causa Operária (Worker's Cause Party)

DEM - Democratas (Democrats)

PDT - Partido Democrático Trabalhista (Democratic Labour Party)

PHS - Partido Humanista da Solidariedade (Humanist Party of Solidarity

PMDB - Partido do Movimento Democrático Brasileiro (Brazilian Democratic Movement Party)

PMN - Partido da Mobilização Nacional (Party of National Mobilization)

PP - Partido Progressista (Progressive Party)

PPS - Partido Popular Socialista (Socialist People's Party)

PR - Partido da República (Party of the Republic)

PRB - Partido Republicano Brasileiro (Brazilian Republican Party)

PRP - Partido Republicano Progressista (Progressive Republican Party)

PRTB - Partido Renovador Trabalhista Brasileiro (Brazilian Labour Renewal Party)

PSB - Partido Socialista Brasileiro (Brazilian Socialist Party)

PSC - Partido Social Cristão (Christian Social Party)

PSDB - Partido da Social Democracia Brasileira (Brazilian Social Democracy Party)

PSDC - Partido Social Democrata Cristão (Christian Social Democratic Party)

PSL - Partido Social Liberal (Social Liberal Party)

PSOL - Partido Socialismo e Liberdade (Socialism and Freedom Party)

PSTU - Partido Socialista dos Trabalhadores Unificado (Unified Workers' Socialist Party)

PT do B - Partido Trabalhista do Brasil (Labour Party of Brazil)

PT - Partido dos Trabalhadores (Workers' Party)

PTB - Partido Trabalhista Brasileiro (Brazilian Labour Party)

PTC - Partido Trabalhista Cristão (Christian Labour Party)

PTN - Partido Trabalhista Nacional (National Labour Party)

PV - Partido Verde (Green Party) 